\title{
Surviving to Thriving: Advancing the Institutional Mission
}

Brinley Franklin

University of Connecticut - Storrs, brinley.franklin@uconn.edu

Follow this and additional works at: https://opencommons.uconn.edu/libr_pubs

Part of the Library and Information Science Commons

\section{Recommended Citation}

Franklin, Brinley, "Surviving to Thriving: Advancing the Institutional Mission" (2011). Published Works. 36.

https://opencommons.uconn.edu/libr_pubs/36 


\title{
Surviving to Thriving: Advancing the Institutional Mission
}

\author{
BRINLEY FRANKLIN \\ University of Connecticut Libraries
}

\begin{abstract}
Academic research libraries can employ several approaches to advance the institutional mission. First, libraries can shift from goals focused on collections and traditional library services and instead align with their campus academic plan and an emphasis on supporting the institution's strategic initiatives. A second approach is for libraries to modify their organizational structures from being function-based on the tasks that traditional libraries performed (e.g., public services, technical services, collection development) and move instead toward organizational units that directly support their university's missions (e.g., undergraduate education; graduate and professional education; research, scholarship, and creative activity; and public engagement). The key is to have library staff engaged in work that contributes to vital institutional outcomes such as student success and faculty research productivity. Academic research libraries should also continue to work towards an assessment program that demonstrates the value of the academic research library in providing quality services that advance the institutional mission.
\end{abstract}

KEYWORDS academic libraries, change management, library customer service, alignment, organization structure, strategic planning, metrics, assessment

The late twentieth and early twenty-first century have seen unprecedented changes in the nature of academic research libraries. Prior to that time, the library's role on campus was reasonably well-defined and consistent from year-to-year and campus-to-campus. The library was expected to provide undergraduate students with a quiet place to study, access course reserve materials, and use the library's indexes, abstracts, and print collections to write papers for their courses. Librarians' roles as selectors, catalogers, and guardians of the university's print collections were understood by the campus community and library staff members were predominantly focused on what occurred inside the library, including the provision of reference and circulation services.

Rapid technological innovation and new ways of learning and conducting research changed these comfortable library traditions dramatically. Academic research libraries shifted their priorities to redesigning learning and research spaces, licensing and providing access to electronic resources, teaching the campus community how to access information in the new information environment, and working directly with faculty and students on teaching and research teams. Then, just as academic research libraries were settling into these new behaviors, the worst recession in seventy-five years occurred, forcing many academic research libraries to concern themselves with survival and making difficult decisions based on reduced levels of funding.

\section{SURVIVING}

Carla Stoffle has been a leader in promoting the need for academic research libraries to change and become more future-focused. For at least fifteen years, she has been saying "The choice is clear. Change now and choose our futures. Change later, or not at all, and have no future." She also prophesized fifteen years ago that "economics will drive libraries - especially large research 
libraries to make organizational, structural, and cultural changes to maintain their roles as vital contributors to teaching and learning in their institutions.

Economics did indeed come to the forefront in 2008/2009 and, as predicted, the great recession forced many academic research libraries to consider redefining their roles in the face of sudden and sometimes significant budget cuts. The effects of the global economic downturn on research libraries were well documented by Charles Lowry, Executive Director of the Association of Research Libraries (ARL). Based on a survey of ARL libraries, Lowry reported in 2009 that $55 \%$ of the participating ARL libraries had experienced either base budget or one-time budget reductions in FY 2008-2009. The average reductions were in the 3\% range, but some libraries reported reductions as high as $10 \%$. Staffing losses were most common, with $73 \%$ of the participating libraries reporting staffing reductions; about half of the ARL libraries experiencing staff reductions also cut operations and/or acquisitions budgets.

The economic situation for ARL libraries in Fiscal Year 2009/2010 continued to be difficult, based on a follow-up survey. Of the 67 ARL libraries that reported budget reductions in FY 2008/2009, 74\% reported budget reductions the following year as well, with half of those in the less than 5\% range and the other half in the 5\% or higher range. In FY 2009/2010, 77\% of the ARL libraries experienced budget cuts; the average reduction was $5 \%$. The two percent reporting budget increases averaged about $3 \%$ gains, roughly equivalent to an inflationary adjustment.

At the University of Connecticut (UConn), the Libraries' budget was reduced by $3.5 \%$ at the beginning of FY 2008/2009, resulting in the loss of 5.5 full-time equivalent (FTE) positions. Twelve months later, an early retirement incentive program was offered and nine library staff, representing 8.5 FTE, opted to participate. In the course of a year, the number of permanent library staff positions was reduced from 116 FTE to 102 FTE. A hiring freeze had also been instituted and, through normal attrition, seven other positions were vacant, leaving the library to function with 95 positions at the start of FY 2009/2010, an 18\% reduction in the number of filled library staff positions in a twelve month period.

The UConn Libraries were surviving, but its continuous improvement efforts were stalled. The Libraries began conducting its own user surveys and subsequently $\mathrm{LibQUAL}^{+\circledR}$ on a regular basis in 1996, and between 1996 and 2004 the Libraries' overall satisfaction score as measured by the two surveys had improved by $12 \%$. Overall satisfaction in 2006 as measured by the local survey had returned to its 2001 level (4.04 on a 5.0 scale). Overall satisfaction as measured by LibQUAL ${ }^{+}$had improved by $4 \%$ between 2000 and 2004, but had only improved by $1.25 \%$ between 2004 and 2008 .

\section{ADVANCING THE INSTITUTIONAL MISSION}

The University of Connecticut adopted a new academic plan, Our World, Our People, Our Future: The University of Connecticut Academic Plan, 2009-2014 at the same time the global economic crisis was occurring and the UConn Libraries were experiencing a leveling off of user satisfaction. The academic plan stated that: 
The University of Connecticut is already one of the top-ranked public research and teaching universities in the country. Our goal is to continue to improve our performance in teaching, research, and service; and our aspiration is to emerge as one of the top-20 public universities in the nation. This Academic Plan will guide our progress in these directions over the next five years, as will our dedication to a set of shared values and standards.

Each of the University's academic units was charged by the Provost with adapting its own strategic plan to support the campus academic plan, which identified three focused areas of excellence: (1) the environment; (2) health and human behavior; and (3) arts, culture, and society.

In addition to the three focused areas of excellence, the University's academic plan called for advancing UConn's standing in five interrelated areas: (1) Undergraduate Education; (2) Graduate and Professional Education; (3) Research, Scholarship, and Creative Activity; (4) Diversity; and (5) Public Engagement.

The University of Connecticut's Executive Vice President and Provost also charged each academic unit with identifying sets of metrics that would measure the unit's success in achieving its strategic plan. Metrics are one way to demonstrate that an academic library is advancing the institutional mission and are a growing assessment trend among ARL libraries. Based on an informal survey directed to the ARL Directors Discussion List by the author on July 21, 2010, eight ARL libraries included metrics in their most recent strategic plan and four additional libraries use metrics as part of their Balanced Scorecard initiatives.

Concurrent with the release of the University's academic plan, the Council on Library and Information Resources (CLIR) released No Brief Candle: Reconceiving Research Libraries for the $21^{\text {st }}$ Century. As the Libraries' strategic planning team began its work, the team was influenced by this publication and, in particular a statement by Andrew Dillon, Dean of the School of Information at the University of Texas:

Academic libraries will survive as long as there are universities. However, libraries cannot thrive without aligning their workings directly to the core mission of their host institution.

The UConn Libraries' strategic plan subsequently was based on the theme of academically supporting the five interrelated areas in which the University was striving to advance its standing: (1) Undergraduate Education; (2) Graduate and Professional Education; (3) Research, Scholarship, and Creative Activity; (4) Diversity; and (5) Public Engagement. Like the University's academic plan, the Libraries' strategic plan for 2009-2014 was organized around five goal statements, each of which corresponded to an area identified in the Academic Plan, such as Undergraduate Education.

Rick Luce pointed out in 2008 that "new organizational models should reflect the environments they are attempting to support, recognizing the synergy and interdependence between scholars 
and information pioneers." After completing its strategic plan, the UConn Libraries reorganized in 2009 with a focus on: (1) aligning the library's organizational structure with the University's Academic Plan goals and structure (2) best serving user needs (3) promoting internal collaboration and (4) positioning the Libraries for the future. The resulting organizational structure placed emphasis on program areas rather than functional areas, with two program areas (Undergraduate Education \& Access Services and the Regional Campus Libraries) primarily concerned with serving undergraduates and two program areas (Library Research Services and Archives \& Special Collections) primarily focused on serving graduate students and faculty. A fifth program area, Central Services, was created to centralize support services such as human resources, financial services, statistics, and information technology services.

The UConn Libraries are comprised of nine physical facilities: Homer Babbidge Library (the main library); Archives and Special Collections (housed in the Thomas J. Dodd Research Center); a Music and Dramatic Arts Library (housed in the School of Fine Arts); a Pharmacy Library (housed in the School of Pharmacy); and five regional campus libraries. A matrix organizational structure was therefore employed so that undergraduate, access, or research services offered at one of the regional campus libraries, for example, had reporting relationships with both their campus library and the Libraries' program area for undergraduate education and access services or library research services. Within the five program areas, twenty standing program area teams were created.

The UConn Libraries aligned their organizational structure, strategic goals, and metrics with the five goals in the University's academic plan; Undergraduate Education; Graduate and Professional Education; Research, Scholarship, and Creative Activity; Diversity; and Public Engagement as follows.

UNDERGRADUATE EDUCATION - The University's strategic goal with respect to undergraduate education was to: "engage our undergraduates in an intellectually challenging and diverse learning environment that combines excellent opportunities in the liberal arts and sciences with strong pre-professional education, co-curricular activities, and research collaborations with members of the faculty."

The Undergraduate Education and Access Services Program Area and the Regional Campus Libraries predominantly serve undergraduate students, who continue to heavily use the Libraries' physical facilities. The Libraries' ten teams focused on serving undergraduate students are comprised of:

- Circulation/Reserves

- Collections Maintenance

- Facilities/Security

- Undergraduate Education

- Resource Access

- The Avery Point Library

- The Greater Hartford Campus Library

- The Stamford Library

- The Torrington Library 
- The Waterbury Library

The Libraries' strategic goal, metrics, and progress after the first year of implementation for undergraduate education are presented in Figure 1.

\begin{tabular}{|c|c|c|c|c|}
\hline \multicolumn{5}{|c|}{$\begin{array}{l}\text { GOAL 1: Undergraduate Education } \\
\text { Actively support our undergraduates with intellectually challenging and diverse resources, } \\
\text { continuous improvement in services, excellent learning environments, and opportunities to } \\
\text { engage in critical thinking that adhere to information literacy standards. }\end{array}$} \\
\hline$\#$ & Metric & $\begin{array}{c}\text { Baseline } \\
2009\end{array}$ & 2010 & $\begin{array}{l}2014 \\
\text { Goal }\end{array}$ \\
\hline 1.1 & $\begin{array}{l}\text { Technology-enhanced group study rooms/spaces for } \\
\text { small group collaboration, student meetings, and } \\
\text { tutoring. }\end{array}$ & 4 & 7 & 10 \\
\hline 1.2 & Libraries-sponsored events aimed at undergraduates. & 1 per year & 10 & $\begin{array}{l}3 \text { per } \\
\text { year }\end{array}$ \\
\hline 1.3 & $\begin{array}{l}\text { Library-wide undergraduate-focused qualitative } \\
\text { assessments of information literacy. }\end{array}$ & 0 & 1 & $\begin{array}{l}1 \text { per } \\
\text { year }\end{array}$ \\
\hline 1.4 & $\begin{array}{l}\text { Faculty initiatives (forums, colloquia, etc) on infusing } \\
\text { information literacy into the curriculum and assessing } \\
\text { student skill development. }\end{array}$ & 1 per year & 7 & $\begin{array}{l}3 \text { per } \\
\text { year }\end{array}$ \\
\hline 1.5 & $\begin{array}{l}\text { Perceived level of service quality ranking of "modern } \\
\text { equipment that lets me easily access needed } \\
\text { information." [relates to LibQUAL+ question IC-5] }\end{array}$ & 7.41 & 7.6 & 8.00 \\
\hline 1.6 & $\begin{array}{l}\text { Perceived level of service quality ranking of library } \\
\text { Web site "enabling me to locate information on my } \\
\text { own."[relates to LibQUAL+ question IC-2] }\end{array}$ & 7.07 & 7.33 & 7.77 \\
\hline 1.7 & $\begin{array}{l}\text { Perceived level of service quality ranking of "quiet } \\
\text { space for individual activities." [relates to LibQUAL+ } \\
\text { question LP-2] }\end{array}$ & 7.07 & 7.22 & 7.77 \\
\hline
\end{tabular}

FIGURE 1 Undergraduate Education Goal, Metrics, and FY 2010 Status

GRADUATE AND PROFESSIONAL EDUCATION - The University's strategic goal for graduate and professional education was to: "sustain and develop select graduate and professional programs of national and international distinction." The Libraries' three teams focused on serving graduate and professional students are the:

- Arts and Humanities Team

- Sciences Team

- Social Sciences Team

The Libraries' strategic goal, metrics, and progress after the first year of implementation for graduate and professional education are presented in Figure 2. 


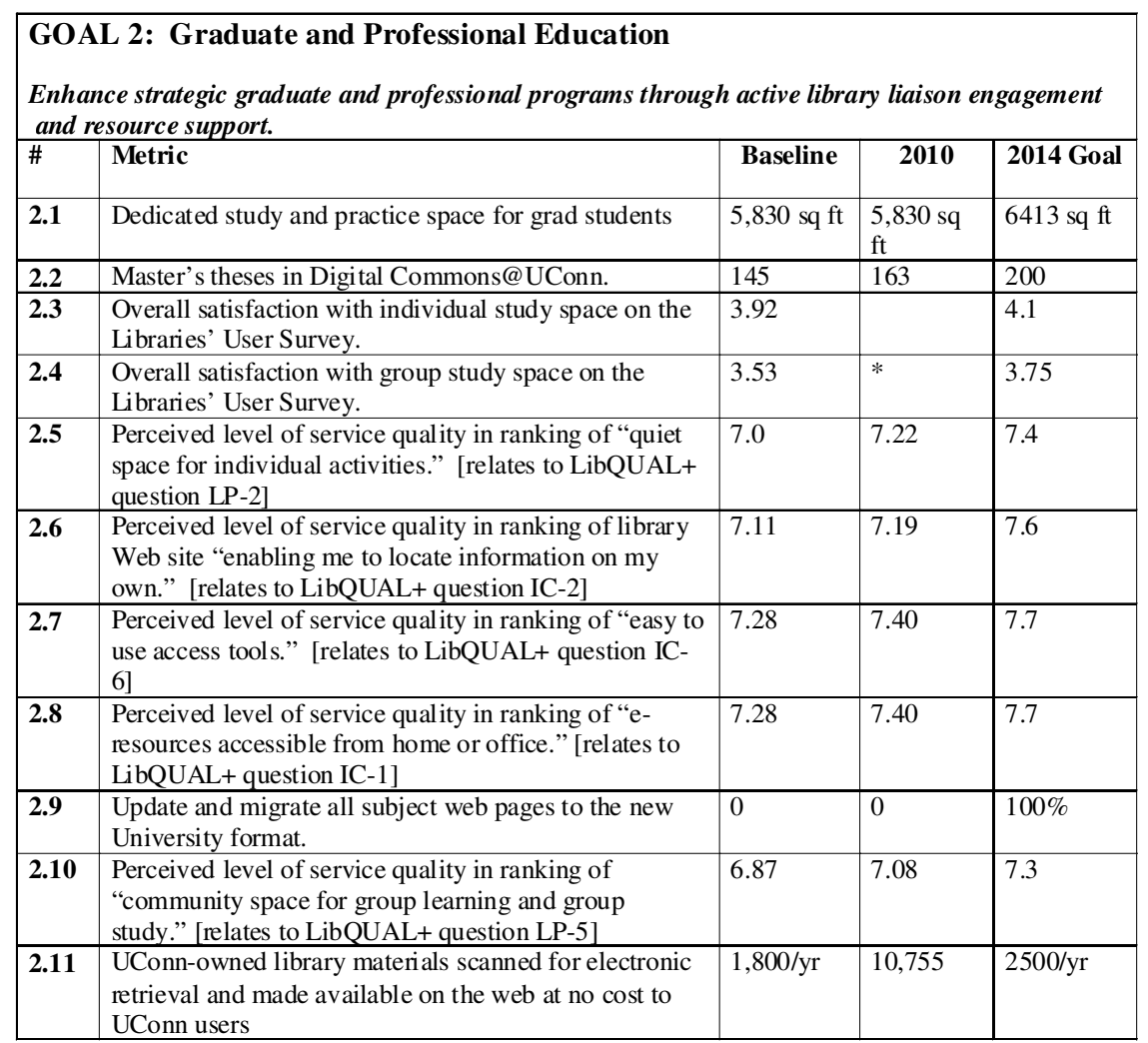

FIGURE 2 Graduate and Professional Education Goal, Metrics, and FY 2010 Status

RESEARCH, SCHOLARSHIP AND CREATIVE ACTIVITY - The University's strategic goal was to: "enhance the benefits to the state, nation, and world from faculty, staff, and student research, scholarship, and creative activity by increasing productivity, building on our existing strengths, and focused areas of excellence, developing a stronger extramural funding portfolio, and expanding the infrastructure that supports research and strengthens our ability to translate new discoveries into practical applications, including our capacity in the area of technology transfer."

As Rick Luce has noted, "librarians must become part of the research process - full members of the research team. To do this, library staff members need to "go native" and embed themselves among the teams they support." The UConn Libraries' staff members focused on research, scholarship, and creative activity reside on the following library teams:

- Arts and Humanities Team

- Sciences Team

- Social Sciences Team

- Digital Programs Team

- Archives and Special Collections

- Conservation

The Libraries' strategic goal, metrics, and progress after the first year of implementation for graduate and professional education are presented in Figure 3. 


\begin{tabular}{|c|c|c|c|c|}
\hline \multicolumn{5}{|c|}{$\begin{array}{l}\text { GOAL 3: Research, Scholarship, and Creative Activity } \\
\text { Actively support faculty, student and staff research, scholarship and creative endeavors through } \\
\text { quality instruction, liaison collaboration, collections, and information access. }\end{array}$} \\
\hline \# & Metric & Baseline & 2010 & 2014 Goal \\
\hline 3.1 & Items in DigitalCommons@UConn. & 4,800 & 7,362 & 7,200 \\
\hline 3.2 & $\begin{array}{l}\text { Project partnerships between library and other campus, } \\
\text { government or private entities. }\end{array}$ & 10 & $*$ & 14 \\
\hline 3.3 & Number of e-journals accessible to users. & 62,447 & 69,194 & 75,000 \\
\hline 3.4 & $\begin{array}{l}\text { Number of objects in UConn local digital collections } \\
\text { (an object is defined as having a unique metadata } \\
\text { record) }\end{array}$ & 43,192 & 45,671 & 55,515 \\
\hline 3.5 & $\begin{array}{l}\text { Usage statistics for digitized objects (i.e. unique } \\
\text { views) }\end{array}$ & 573,167 & 933,869 & $1,255,408$ \\
\hline 3.6 & Student and faculty use of the liaison program. & $50 \%$ & $*$ & $70 \%$ \\
\hline 3.7 & Percentage of budget spent on digital format resources. & $80 \%$ & $87 \%$ & $90 \%$ \\
\hline 3.8 & $\begin{array}{l}\text { Annual number of research consultations by academic } \\
\text { liaisons and curators. }\end{array}$ & 2,600 & 3,003 & 3,650 \\
\hline 3.9 & $\begin{array}{l}\text { Perceived level of service quality in ranking of "print } \\
\text { or electronic journal collections needed." [relates to } \\
\text { LibQUAL+ question- IC8] }\end{array}$ & 7.21 & 7.41 & 7.5 \\
\hline 3.10 & $\begin{array}{l}\text { Perceived level of service quality in ranking of } \\
\text { "electronic information resources needed." [relates to } \\
\text { LibQUAL+ question IC-4] }\end{array}$ & 7.21 & 7.48 & 7.5 \\
\hline
\end{tabular}

FIGURE 3 Research, Scholarship, and Creative Activity Goal, Metrics, and FY 2010 Status

DIVERSITY - The Libraries adopted the University's goal related to diversity and created a crossprogram Diversity Advisory Team, reporting directly to the Vice Provost for University Libraries. Two distinct strategies were established to advance the Libraries diversity efforts. The first was to create more opportunities for interaction with people from different cultures and backgrounds, including the recruitment and retention of library staff from underrepresented groups. To-date, five of the thirteen library staff recruited since the strategic plan was adopted have been from underrepresented groups. The second strategy was to strengthen the Libraries' programs that promote cultural competency among faculty, staff, and students. The Libraries' strategic goal, metrics, and progress after the first year of implementation with respect to diversity are presented in Figure 4.

\begin{tabular}{|c|c|c|c|c|}
\hline \multicolumn{5}{|c|}{$\begin{array}{l}\text { GOAL 4: Diversity } \\
\text { Ensure an enriched learning and work environment by creating a more inclusive community } \\
\text { that recognizes and celebrates individual differences. }\end{array}$} \\
\hline$\#$ & Metric & Baseline & 2010 & $\begin{array}{l}2014 \\
\text { Goal }\end{array}$ \\
\hline 4.1 & $\begin{array}{l}\text { Professional library staff from underrepresented } \\
\text { groups. }\end{array}$ & $10 \%$ & $15 \%$ & $14 \%$ \\
\hline 4.2 & $\begin{array}{l}\text { Retention rate of professional library staff from } \\
\text { underrepresented groups (i.e., those who remain at } \\
\text { UCL for more than five years). }\end{array}$ & $50 \%$ & $50 \%$ & $60 \%$ \\
\hline 4.3 & $\begin{array}{l}\text { Primary resource collections documenting } \\
\text { underrepresented groups. }\end{array}$ & 44 & 50 & 50 \\
\hline 4.4 & Public programs per year related to diversity. & 4 & 11 & 6 \\
\hline 4.5 & Exhibits per year related to diversity. & 3 & 5 & 5 \\
\hline
\end{tabular}

FIGURE 4 Diversity Goal, Metrics, and FY 2010 Status 
PUBLIC ENGAGEMENT - The Libraries adopted the University's goal related to public engagement and created a Public Programming, Marketing, and Communications Team that supplemented the Libraries' program areas' efforts with respect to public engagement. The Libraries' public engagement strategic goal, metrics, and progress after the first year of implementation are presented in Figure 5.

\begin{tabular}{|c|c|c|c|c|}
\hline \multicolumn{5}{|c|}{$\begin{array}{l}\text { GOAL 5: Library Support for Public Engagement } \\
\text { Enhance the contributions of UConn Libraries' staff to the state, nation, and world through } \\
\text { public programming and appropriate collaboration with partners in the public and private sectors. }\end{array}$} \\
\hline \multicolumn{5}{|c|}{ Baseline } \\
\hline \multicolumn{5}{|c|}{\begin{tabular}{l|l}
5.1 & Regis
\end{tabular}} \\
\hline & \multirow{4}{*}{\begin{tabular}{|l|} 
Public use/rentals of Library facilities (non-UConn) \\
Oral histories of Connecticut citizenry. \\
Public engagement-related digital collections. \\
Annual consultancies to public sector organizations. \\
\end{tabular}} & & & \\
\hline & & 804 & 1,17 & 900 \\
\hline & & & 4 & \\
\hline & & & & \\
\hline
\end{tabular}

FIGURE 5 Public Engagement Goal, Metrics, and FY 2010 Status

The Libraries developed a database management system, the Research, Instruction, and Outreach (RIO) tool to capture the research consultation, instruction, and outreach efforts of its library staff system wide. Similar to Welserve, a database management system developed at Johns Hopkins University's Welch Medical Library to capture data about informationists' direct service contacts with its research, academic, and clinical units, the University of Connecticut Libraries staff members utilize the RIO tool which captures this data so that reports can be generated indicating the research consultation, instruction, and outreach efforts by campus, activity type, staff member, date, and campus.

Reports provide data that can be used to track trends across activity types by academic disciplines and/or academic populations. This information is used for discussion and decision making purposes for future consideration in service offerings, staffing, outreach, and staff training purposes.

In addition to straightforward research consultations, instruction sessions, and public programming activities, the RIO tool has the capacity to capture data for the following activities:

- Unique library supported efforts in support of faculty and graduate student research needs such as NSF data management workshops;

- Subject specialist support of information literacy expectations for upper classmen within an academic discipline;

- Citation management, grant and doctoral research workshops to support individual and collaborative research efforts; and

- Use of the library facilities for education, cultural and course related functions.

A cross-program team, the UConn Libraries' Survey and Assessment Team, works with the Comptroller's Office when the University of Connecticut submits its Facilities and Administrative (F\&A) rate proposal to the U.S. Department of Health and Human Services. In 
Fiscal Year 2008/2009, the Libraries assigned its costs to specific library activities, surveyed inhouse users at its main library, and surveyed all electronic resources users by employing the MINES ${ }^{\mathrm{TM}}$ methodology. This cost analysis study determined that $7 \%$, or $\$ 2.2$ million of the Libraries' total costs of $\$ 31.5$ million directly supported funded research on-campus and were recoverable from the federal government through the University's F\&A rate. Almost 84\% of the Libraries' expenses were in support of the University's teaching and learning functions; about 9\% supported other institutional activities. The study also informed library staff which types of users and schools on campus were physically using the main library and its services as well as providing demographic characteristics of electronic resources users without compromising their anonymity.

\section{THRIVING}

In the fall of 2009, the Libraries were given permission to refill three positions that had been lost that summer as part of the University's retirement incentive program. This was an opportunity for the Libraries to begin to re-conceptualize its staffing in the framework of its strategic planning goals and the changing library environment. Each of the five program areas made recommendations on new staff positions and from among these: a sciences librarian was selected to support researchers in civil and environmental engineering, electrical and computer engineering, and mechanical engineering; an applications developer was selected to support the Libraries' digital programs; and a media technology coordinator was selected to support the growing use of media in teaching and public programming offered in and by the Libraries. The Libraries were also allowed to fill four positions that had been vacated due to normal attrition.

The Libraries received permission, in the summer of 2010, to recruit six more positions as justified by the University's academic plan. This enabled the Libraries to recruit an additional undergraduate education librarian to staff evening and weekend hours in the Learning Commons, another metadata librarian, an electronic resources management librarian, a computer workstation coordinator, an additional Arts and Humanities Librarian, and a second accountant to provide additional cost analysis capabilities.

In November, 2010, the UConn Libraries, led by its Survey and Assessment Team, re-employed LibQUAL $^{+\circledast}$ for the first time since adopting the new strategic plan and organizational structure and with ten new staff in place. Almost 2,500 undergraduate students, graduate students, and faculty participated in the LibQUAL ${ }^{+\circledast}$ survey and a representative sample was collected. It was the UConn Libraries first opportunity to see if the Libraries were making measurable progress toward achieving their 2014 target metrics in the strategic plan.

The results were encouraging. Overall LibQUAL ${ }^{+\circledast}$ satisfaction scores improved between 2008 and 2010 at each of the Libraries' nine physical locations and for each of the primary user groups: undergraduate students; graduate students; and faculty (see Figure 6). The Libraries' 2010 perceived quality scores improved over the 2008 perceived quality scores on all twenty-two questions. 


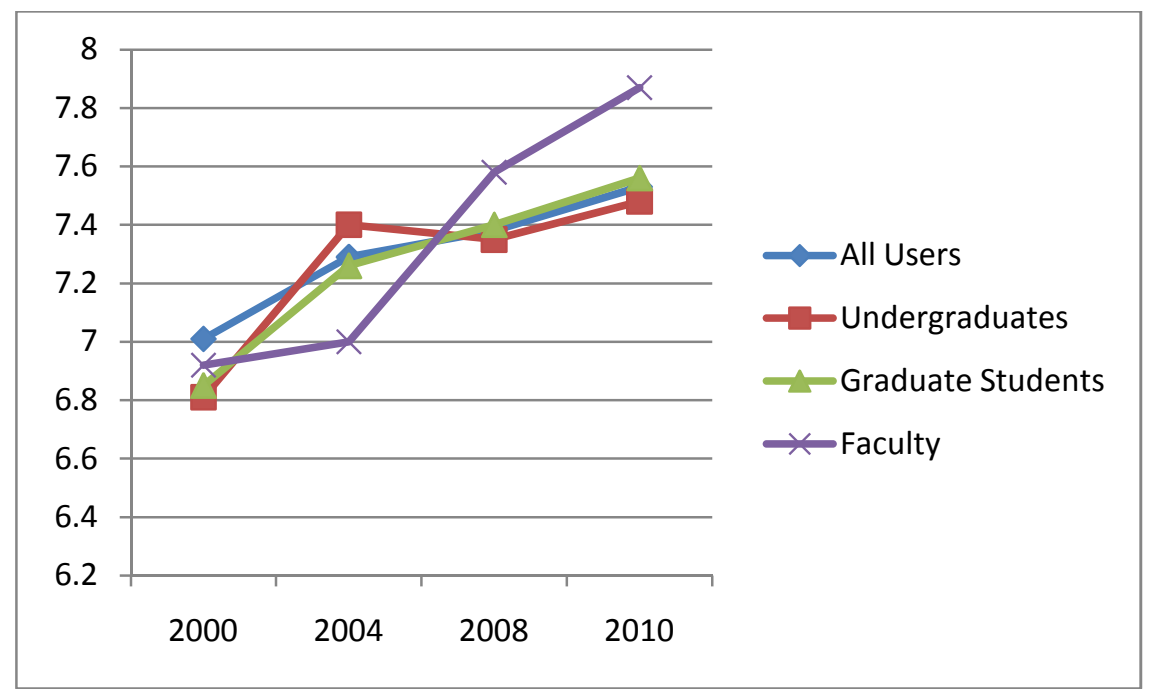

FIGURE 6 University of Connecticut Libraries Overall Service Quality Scores by Type of User, 2000-2010

The average perceived score for all users combined also improved significantly between 2008 and 2010, an improvement over the small increase in perceived level of service that occurred between 2004 and 2008 (see Figure 7).

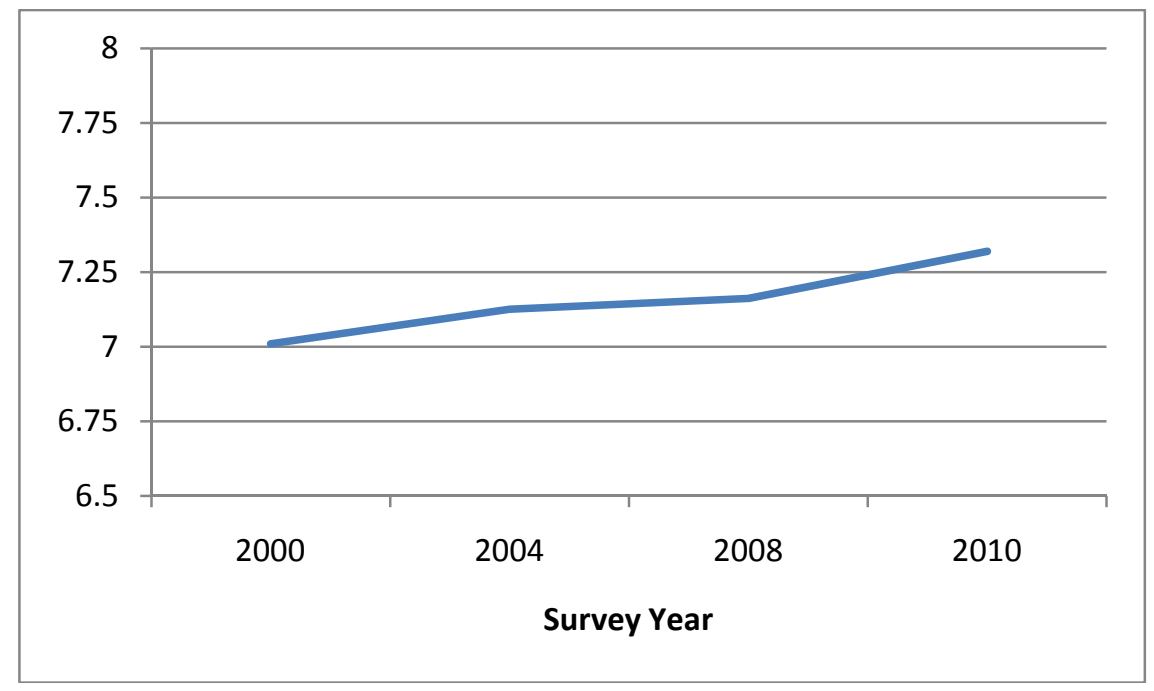

FIGURE 7 University of Connecticut Libraries Average Perceived Service Quality Score, 2000-2010

The UConn Libraries' average perceived LibQUAL ${ }^{+\circledR}$ score of 7.32 from all users in 2010 compared favorably to the scores from the libraries at the University's eight peers based on each of their most recent LibQUAL ${ }^{+}{ }^{\circledR}$ implementations (see Figure 8). The UConn Libraries' overall service quality scores (7.53) for all users, graduate students (7.56) and faculty (7.87) were the highest among its peers and its overall service quality score (7.48) for undergraduate students ranked second in comparison to UConn's eight peers. 


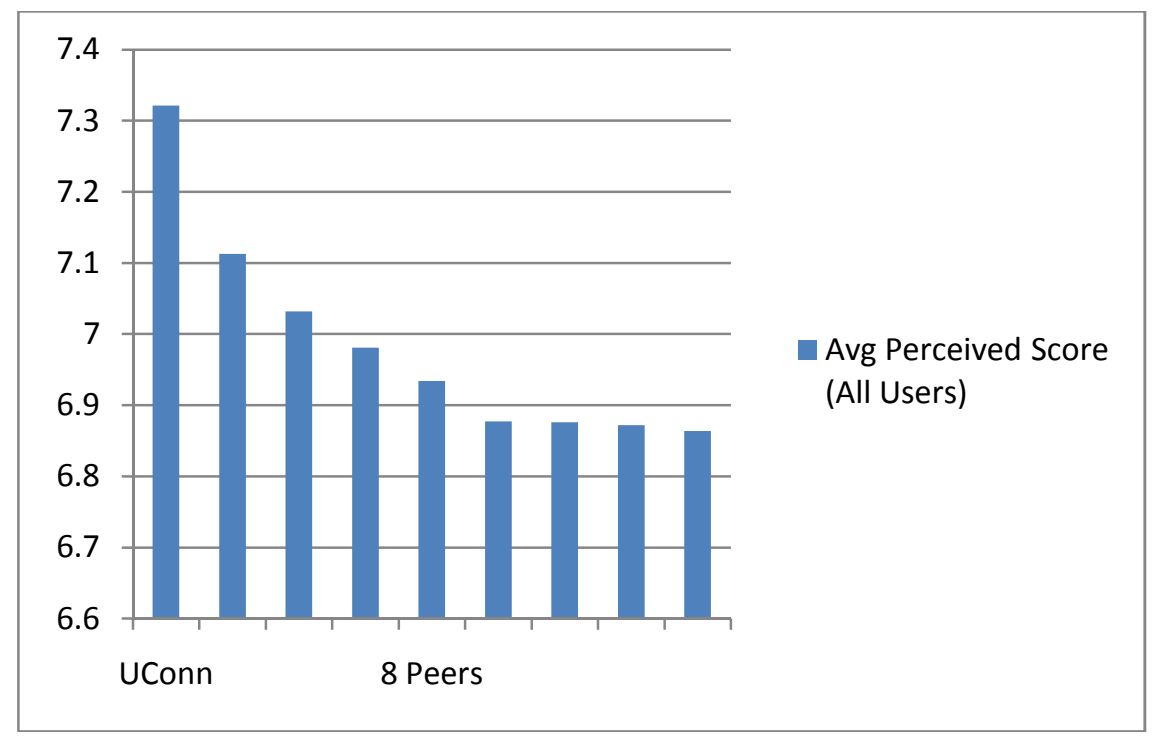

FIGURE 8 Average Perceived Scores for All Users - University of Connecticut Libraries and its 8 Peers

A strategic plan and organizational structure based on institutional mission changes the focus of library staff from the library and its functions to its users and their needs. It generates campus buy-in and helps the library's constituencies to better understand the library and its services by adopting language and terminology derived from the University academic plan. Incorporating metrics related to an academic library's performance can help demonstrate the value of the academic research library in providing quality services that advance the university's primary missions and overarching institutional outcomes such as student success and faculty research, scholarship, or creative activity.

\section{REFERENCES}

Craven, C., Goode V., Twose C., Zhang, D. \& Roderer, N. (2010) WelServe: the DBMS for capturing and tracking Welch Medical Library's embedded informationist service delivery at Johns Hopkins University. Journal of Library Administration (50) 397-411.

Dillon, A. (2008). Accelerating learning and discovery: Refining the role of academic librarians. In No brief candle: reconceiving research libraries for the $21^{\text {st }}$ century. Washington, D.C., Council on Library and Information Resources, 51-57.

Franklin, B. (2009) Aligning library strategy and structure with the campus academic plan: a case study. Journal of Library Administration (49)5, 495-505.

Franklin, B. \& Plum, T (2006). Successful web survey methodologies for measuring the impact of networked electronic services (MINES for Libraries). IFLA Journal (32)1, 28-40.

Lowry, C.B. (2009) The future ain't what it used to be so when you come to a fork in the road, take it. SPARC-ACRL Forum. Retrieved from http://www.sparcspaces.org/video/2009/08/sparc-acrl-forum-2009-charles-b-lowry-phd/

Lowry, C.B. (2011) Year 2 of the great recession: Surviving the present by building the future. Journal of Library Administration, 51(1), 37-53. 
Luce, R. (2008) A new value equation challenge: the emergence of eResearch and roles for research librarians. In No brief candle: reconceiving research libraries for the $21^{\text {st }}$ century. Washington, D.C., Council on Library and Information Resources, 42-50.

Stoffle, C.J., Renaud, R. \& Veldof, J.R. (1996) Choosing our futures. College and Research Libraries, 57(3), 213-225.

Stoffle, C. (1995) The upside of downsizing: Using the economic crisis to restructure and revitalize academic libraries. In C. Laguardia, S. Bentley, and J. Martorana (Eds.), The upside of downsizing: Using library instruction to cope (pp. 1-13). New York, NY: Neal Schuman.

University of Connecticut (2008). Office of the Executive Vice President and Provost. Our World, Our People, Our Future: The University of Connecticut Academic Plan, 20092014. Retrieved from http://academicplan.uconn.edu/ 